Pamiętnik Literacki 2021, 3, s. 143-162
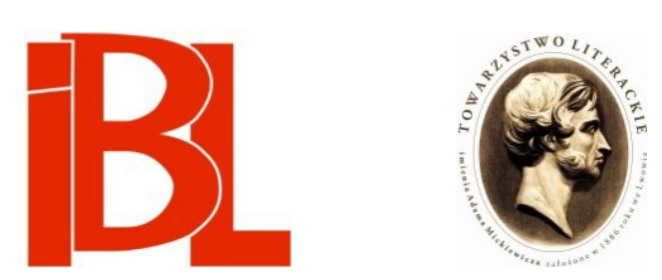

\title{
Najmniejsza powszechność. O Norwidowskiej skali aktywizmu
}

Christian Zehnder 


\section{NAJMNIEJSZA POWSZECHNOŚĆ O NORWIDOWSKIEJ SKALI AKTYWIZMU}

W norwidologii daje się ustalić dość szeroki konsensus dotyczący Norwidowskiego dyskursu związanego $\mathrm{z}$ intelektualnym umiarem. Ową ogólną zgodę można sprowadzić do następującego sądu: „gorączce romantycznej” poeta programowo przeciwstawiał powściagliwość w pisemnym wyrazie, czyli wierność „literze”, wnikliwą analizę oraz troskliwe kultywowanie tradycji; ryzyku regresji do melancholii „u my sł u - s ta o ś ć” (Praca. PW-1 388; Prac-czoło. PW-2 91) ${ }^{1}$; samooślepieniu przez frenezję - świadomość obowiązków. Wytrwała praca mająca na celu powolne przekształcanie rzeczywistości to cnota, która u poety kontrastuje $z$ tęsknota za nagłym nowym początkiem, $\mathrm{z}$ romantyczną żądzą przejścia $\mathrm{z}$ historii $\mathrm{w}$ absolutną równoczesność, w millenarystyczna „rzeszę ducha”. W tej perspektywie narodziła się zresztą paradygmatyczna Norwidowska krytyka romantycznego kultu ofiarnego. Wystarczy wspomnieć o „uniepotrzebnieniu męczeństw”, jednym z najsłynniejszych haseł autora Promethidiona (PW-3 467).

W dziejach recepcji obraz „trzeźwego” Norwida wielokrotnie niuansowano; twórce opisywano jako „poetę historii”, „poetę kultury”, „poetę pracy”, „poetę dialogu” itp. Do tych określeń niedawno dołączyła propozycja zwania go „poetą hermeneutyki”, którą można streścić jako formułę bardzo otwartą pod względem teoretycznym, kładącą nacisk na archeologiczne podejście do przeszłości, na skrupulatne „czytanie” społeczeństwa jako alternatywy dla wywoływania nowego świata w duchu romantycznego kreacjonizmu².

Jednakże twórczość Norwida właśnie w geście ostrzegania przed duchowym ekscesem sama była „szkoła gorliwości”, co trafnie zauważył Czesław Miłosz ${ }^{3}$. A jeśli wątpliwości co do naszkicowanego obrazu (odpowiedzialna samokontrola versus niebezpieczne wywyższenie ducha) są uzasadnione, to nie tylko dlatego, że opierają się wyłącznie na skrajnie uogólniającej konstrukcji „wysokiego” romantyzmu (głównie Mickiewiczowskiego) ${ }^{4}$. Tę rezerwę można heurystycznie ująć w nawias.

1 W ten sposób odsyłam do wydania: C. N o rwid, Pisma wszystkie. Zebrał, tekst ustalił, wstępem i uwagami krytycznymi opatrzył J. W. Gomulicki. T. 1-11. Warszawa 1971-1976, s. 467. Liczba po dywizie oznacza tom, a po spacji - stronicę.

2 Zob. P. A b r is ze w s k a, Hermeneutyka literacka Cypriana Norwida. Lublin 2011. - M. K u zi a k, W stronę hermeneutyki Norwida. „Studia Norwidiana” t. 34 (2016), s. 239.

Cz. Miłos z, Ogród nauk. Paryż 1979, s. 15.

Warto przypomnieć hasło „Le romantisme, c'est la révolution [Romantyzm to rewolucja]”, na które w swoich wykładach na temat romantyzmu powołał się I. B e rli n (The Roots of Romanticism. Ed. 
Podstawowym problemem będzie raczej to, że taka typologia umiejscawia Norwida w literacko-historycznej próżni. W rzeczy samej nic nie wskazuje na to, że autor Quidama chciał unieważnić romantyzm. Zmierzał raczej do jego przekształcenia.

\section{„Literatura-czynu" jako pomniejszenie}

Jednym $z$ elementów, które przetrwały przy owej transformacji, był romantyczny „czyn”. Wątek ów czasami zaniedbywano, zwłaszcza gdy projekt Norwida rekonstruowano pod auspicjami hasła „pracy” i praktyki „sztuki-pracy”. Najwyraźniejszym dowodem uporczywości „czynu” również w utworach poety z okresu średniego jest przedmowa do poematu Niewola. Rapsod (1849). Norwid analizuje w niej, jak polska literatura miała się rozwinąc w bliskiej przyszłości: po fazie inspiracji i „mistycznego” dążenia do „nieograniczoności” narodowe piśmiennictwo „c zy n ny przyjmie kierunek” i wstapi „w sferę drugą (na wstępie do której stoi dzisiaj), w sferę li t e r a t u ry - c zy n u" (PW-3 365-366). Tymczasem - chciałoby się powiedzieć „literatura-czynu” była zamiarem Mickiewicza przedstawionym w prelekcjach paryskich ponad pięć lat wcześniej. Bądź co bądź, w przedmowie do Niewoli Norwid twierdzi tylko tyle: romantyzm „mistyczny” ma być zastapiony przez literaturę „praktyczną". Mglistej totalności poeta zdaje się przeciwstawiać pewną zorganizowaną pluralność, zarazem nie kwestionuje doniosłości literatury i sztuki. Chociaż może właśnie w jego niezwykłej waloryzacji sztuki tkwi zarzut pod adresem romantyzmu, któremu sama sztuka przecież nigdy nie wystarczała i który zawsze dążył poza jej granice.

Decydujący zwrot można upatrywać w specyficznej aktualizacji postaci Prometeusza. Jak wiadomo, słowo „Promethidion” oznacza 'dziecko Prometeusza', możliwy zaś jest też sens 'mały Prometeusz'. Cenne wskazanie w tym kontekście daje model prometeizmu romantycznego z klasycznej rozprawy Harolda Blooma Internalizacja romansu poszukiwań $w$ angielskiej poezji romantycznej (1969). Badacz angielskiego romantyzmu pisze:

Ogólnie mówiąc, Prometeusz to poeta-jako-bohater w pierwszym stadium swego poszukiwania, charakteryzującym się głębokim zaangażowaniem w polityczną, społeczną i literacką rewolucję oraz bezpośrednim, satyrycznym nawet, atakiem na zinstytucjonalizowane ortodoksje europejskiego [...] społeczeństwa, łącznie $z$ historyczną orientacją chrześcijaństwa i neoklasyczną tradycją literacką i intelektualną, szczególnie w jej fazie oświeceniowej. Prawdziwy Człowiek, Wyobraźnia, wyłania się po strasznych kryzysach, w głównym stadium romantycznego poszukiwania, odznaczającym się stosunkowo nikłym zaangażowaniem w działalność rewolucyjną i odsunięciem się od polemiki i satyry, aby terenem poszukiwań uczynić jaźń i jej zagadki ${ }^{5}$.

Sądzę, że uzasadnione jest powiązanie romantyzmu Mickiewiczowskiego z taką typologia prometeizmu rewolucyjnego. Francuski polonista Jean Fabre kilka lat przed Bloomem zaproponował podobną formułę: „romantyzm energetyczny”, który miał się przerodzić w „romantyzm nostalgiczny”6. W świetle koncepcji Fabre’a war-

H. H a r dy. Princeton 1999, s. 15), a które to hasło wydawcy określają w przypisach jako „niezlokalizowane" (ibidem, s. 152).

5 H. Blo o m, Internalizacja romansu poszukiwań $w$ angielskiej poezji romantycznej. Przeł. M. B. F ed e w i c z. „Pamiętnik Literacki” 1978, z. 3, s. 270-271.

6 J. F abre, Oświecenie a romantyzm - wstęp. Przeł. E. Rz a d k ow s ka. Jw., 1970, z. 2. 
to poczynić zastrzeżenie dotyczące Bloomowskiego pojęcia internalizacji. Romantyzm Mickiewiczowski przecież od początku jest „wewnętrzny”, a rosnący nacisk na emocje nie wyklucza zewnętrznego aktywizmu. W prelekcjach paryskich (zbrojny) „czyn” Słowian pojawia się przecież dzięki „człowiekowi wewnętrznemu”. Ale owo upraszczające rozumienie romantyzmu nie stanowi dla nas, powtarzam, większego problemu. Istotniejsze wydaje się to, jak przyczynia się ono do typologicznego umiejscowienia twórczości Norwida. Otóż mając na uwadze modele Blooma i Fabre’a, możemy mówić o późnoromantycznej anomalii, która - o ile wiem - nie została dotąd opisana w literaturze przedmiotu: prometeizm Norwida bynajmniej nie stanowi „stosunkowo nikłego zaangażowania w działalność rewolucyjna”, czyli nie jest internalizacją romantyzmu rewolucyjnego ani zwrotem ku nostalgii. Jest natomiast redukcja aktywizmu w skali: pomniejszeniem. Dlatego więc Prometeusz wraca jako Promethidion.

W Dumaniu [II] (1841), jednym z wczesnych wierszy Norwida, czytamy, że należy „Z czynem, $\mathrm{z}$ wielkim czynem, jak z oszczepem w dłoni / Lub z palmą, iść” (PW-1 43) ${ }^{7}$. Retorycznie rzecz biorac, obraz wielkiego czynu w ręce to chyba synekdocha, na pewno hiperbola. Ale wyraźna tendencja do pomniejszenia jest więcej niż chwytem retorycznym. Staje się rzeczywistościa, jak gdyby eksperymentalnym watkiem Norwidowskiego pisania. Jeśli chcemy skonkretyzować myśl o Norwidowskim „mesjanizmie sztuki” około $1850 \mathrm{roku}^{8}$, musimy przede wszystkim zrozumieć, że wynika on ze zmiany skali.

\section{„To, co małe” jako wielkość - spojrzenie na biedermeier i Adalberta Stiftera}

W dalszych częściach artykułu będę omawiał teksty Norwida $z$ lat pięćdziesiąych XIX wieku, w których na różne sposoby zmniejsza się skala aktywizmu. Zanim przejdę do tych przykładów, chciałbym wyjaśnić pojęcie „małego” i jego funkcje w moim studium. Otóż najzupełniej obcy poecie jest pomysł ucieczki w „kółko” czy też w „małe szczęście”, charakterystyczne dla współczesnego Norwidowi biedermeieru, ale zarazem dla romantyzmu o bardziej kwietystycznych tendencjach ${ }^{9}$. Przed laty Janusz Maciejewski podją się biedermeierowskiej lektury Norwida ${ }^{10}$. Wynik tej próby nie jest trudny do streszczenia: Norwida wiążą z ową szkołą odwrót od świata zjawisk niezwykłych, zwłaszcza od demonicznych bohaterów-geniuszów, oraz ogólne nastawienie praktyczne. Wyraźnie różnią go natomiast od założeń literatury biedermeierowskiej, według zestawienia Maciejewskiego, nacisk na problematykę moralną, stała troska o społeczną relewantność sztuki, a także niepokój poszukującego wędrowca.

8 Zob. Z. Troj a n ow i c z ow a, Cypriana Norwida mesjanizm sztuki, czyli o poszukiwaniu „wszech-doskonałości”. W: Romantyzm. Od poetyki do polityki. Interpretacje i materiały. Wybór, red. A. A r twińska, J. Borowczyk, P. Śniedziewski. Kraków 2010.

9 Zob. wiersz Kółko, nr LV w Vade-mecum (PW-2 84). Punktem odniesienia może być epigramat K. Brodzińskiego (Wybór pism. Oprac. A. Witkowska. Wrocław 1966, s. 153):

Czyń każdy w swoim kółku, co każe duch Boży,

A całość sama się złoży.

J. M a ci e jew s ki, Cyprian Norwid. Warszawa 1992, s. 116, 119. 
Przywołanie biedermeieru w rekonesansie Maciejewskiego opiera się głównie na opisaniu tej formacji w jej polskim wydaniu (m.in. Henryk Rzewuski, Michał Grabowski, Wincenty Pol, Józef Korzeniowski, Józef Ignacy Kraszewski) ${ }^{11}$. Warto się jednak zastanowić, czy kult „małego” w biedermeierze koniecznie ma charakter nostalgiczny, właśnie kwietystyczny. Czy nie może być tak, że w rzekomym wycofaniu kryje się dynamika o doniosłości nie tylko wewnętrznej? Jeśli spojrzeć na innego przedstawiciela biedermeieru, mianowicie na austriackiego pisarza i malarza Adalberta Stiftera (1805-1868), taka hipoteza wydaje się uzasadniona. Chciałbym ją najpierw skonkretyzować i rozwinąć, aby następnie zastosować do analizy Norwidowskiej skali aktywizmu. Pozwolę sobie przytoczyć koncepcję „tego, co małe” (,das Kleine”) z jednego z najbardziej znanych tekstów Stiftera, nie zakładając, rzecz jasna, bezpośredniego związku między autorem Der Nachsommer (Późne lato, 1857) a Norwidem. Myślę o przedmowie do zbioru opowiadań Bunte Steine (Kolorowe kamienie, 1853), w którym Stifter wprowadza słynną koncepcje „łagodnego prawa” („das sanfte Gesetz") ${ }^{12}$. Autor rozumie przez to swoistą niepozorną siłę, która ma przenikać wszelkie zjawiska przyrody i historię człowieczeństwa. Odkryciu tej siły łagodnego prawa - towarzyszy w przedmowie właśnie zwrot ku „temu, co małe”. Pisze Stifter:

Skoro już [...] mowa o tym, co wielkie, i tym, co małe [w oryginale: „von dem Großen und Kleinen”], pragnę zaprezentować własne poglądy, które prawdopodobnie odbiegają od mniemań wielu innych ludzi. Powiew wiatru, toczenie się wód, dojrzewanie zbóż, falowanie morza, zielenienie się ziemi, lśnienie nieba i migotanie gwiazd uważam za wielkie; wspaniale nadciągającej burzy, rozszczepiających domy piorunów, wichru miotającego pożarem, ziejącej ogniem góry i trzęsienia ziemi, co wstrząsa lądami, nie uważam za większe od tamtych, przeciwnie, uważam je za mniejsze, są bowiem wyłącznie objawem o wiele wyższych praw. Występują na pojedynczych miejscach jako wynik jednostronnych przyczyn ${ }^{13}$.

Fragment ten wyraźnie pokazuje niewspółmierność Norwida z biedermeierowska, idylliczna wizja przyrody. W samej przedmowie Stiftera bodaj więcej jest opisów zjawisk przyrody niż w całej twórczości Norwida, a nawet jeśli krajobrazy spotyka

11 Maciejewski powoływał się na prace M. Żmigrodzkiej i M. Janion z lat sześćdziesiątych XX wieku. Złożone niemieckojęzyczne debaty wokół biedermeieru dokumentuje antologia Spory o biedermeier (Wybór, wstęp, oprac. J. Ku bi a k. Poznań 2006).

12 Opowiadania Stiftera, zawsze mające wymiar niezgłębiony, w bardzo ograniczonym stopniu realizuja program przedmowy, ale to nie musi nas tutaj niepokoić. Zob. A. M a zu r, Anatomia „tagodnego prawa” - między literatura a filozofia. „Przegląd Filozoficzno-Literacki” 2009, nr 2, s. 34-35. Po raz pierwszy podjąłem pomysł odniesienia koncepcji „łagodnego prawa” do twórczości Norwida w korespondencji z R. Fieguthem, który nawiązał do tego w wystąpieniu na uroczystości wręczenia medalu za rozpowszechnianie wiedzy o Norwidzie w Lublinie 16 X 2017 (zob. wersję drukowaną: R. F i g u th, Chrześcijaństwo dla wszystkich. Parę słów nt. „Quidama” C. Norwida. „Studia Norwidiana" t. $37\langle 2019\rangle$, s. 283). Serdecznie dziękuję mu za ten dialog.

13 A. Stift er, Przedmowa do tomu opowiadań „Kolorowe kamienie”. Przeł. A. M a z u r. „Przegląd Filozoficzo-Literacki” 2009, nr 2, s. 20. Przekł. zmodyfikowany. Por. A. Stifter, Vorrede. W: Werke und Briefe. Historisch-kritische Gesamtausgabe. Hrsg. A. D o p ple r, W. Frü hwald. T. 2, cz. 2: Bunte Steine. Buchfassungen. Hrsg. H. B erg n er. Stuttgart 1982, s. 10. Mazur tłumaczy przymiotnik nominalizowany „das Kleine” jako „małość” (oraz „das Große” jako „wielkość”). Rezygnuję z określenia "małość”, gdyż w języku polskim często odnosi się ono do postawy moralnej i ma znaczenie negatywne. W Stifterowskiej waloryzacji zjawisk niepozornych ważne jest rozumienie heurystycznie neutralne. 
się w pismach autora Vade-mecum częściej, niż mogłoby się wydawać, to chyba nie mówimy o łagodnie „toczących się”, lecz raczej o cierpkich, czasami umyślnie bezbarwnych przedstawieniach. Ale abstrahując od tego, że Stifter - w wielkim skrócie - jest poeta przyrody, a Norwid nim nie jest, wypada zauważyć: autorowi Bunte Steine chodzi o pewne przewartościowanie. Przedmowa bowiem nie tyle w melancholijno-ironicznym geście przemilcza głośne fenomeny przyrody jako zjawiska wzniosłości. Stifter przewartościowuje wzniosłą przyrodę, a jej wielkość nazywa „małą" - mniejszą niż procesy przyrody, które są ledwie zauważalne.

$Z$ wielkościa („Größ”) filozofia niemiecka wiązała wzniosłość (,das Erhabene”) ${ }^{14}$. Stifter w przedmowie chyba zgadza się $\mathrm{z}$ wyrażonym w Krytyce władzy sązenia założeniem Immanuela Kanta, według którego doświadczenie wzniosłości stanowi chęć negatywną (,negative Lust"). Natomiast twierdzeniu Kanta, że ta chęć pobudza wyobraźnię do ugruntowania się w nadzmysłowym substracie (,übersinnliches Substrat"), Stifter ewidentnie, choć nie otwarcie zaprzecza (nie używa określenia „das Erhabene”). „Jednostronne” zjawiska wzniosłości, zdaniem Stiftera, nie ogarniają większego zakresu. Wydaje się zatem, że pisarz podąża raczej za Johannem Gottfriedem Herderem, który - wbrew Kantowi - pojmował wzniosłość czysto sensualistycznie i nie przypisywał jej funkcji metafizycznej. Inaczej mówiąc: gruntu metafizycznego Stifter nie szuka w tym, co wielkie, tylko od poczatku w tym, co małe. Autor Der Nachsommer przekładał więc w pewnym sensie cechy wzniosłości w rozumieniu Kanta na zjawiska ciche, niepozorne i w taki sposób przewartościował szeroko wówczas uznaną teorię wzniosłości.

Rzekoma wielkość jest istotnie mniejsza od tego, co małe. Jak Stifter uzasadnia tę „odbiegająca od mniemań wielu innych ludzi” wizję rzeczywistości? Jego decydujący argument brzmi następująco: wzniosłe zjawiska relatywizują się same przez to, że są zaledwie lokalnymi kulminacjami, które wyczerpują się w swej ekstatyczności i - inaczej niż u Kanta - nie prowadzą do subiektywnej reakcji i ostatecznie do obiektywnego utwierdzenia godności podmiotu. Owa logika dewaloryzacji wielkości wydaje się zrozumiała. Trudniejsza jest kwestia, dlaczego to, co małe, ma być „większe” i mniej jednostronne. Innymi słowy: co posiada „małowymiarowe”, czego brakuje temu, co wielkie? Stifter odpowiada na to pytanie co najwyżej pośrednio:

Siła, która sprawia, iż w garnku biednej kobiety unosi się i wylewa mleko, jest tą samą co w siejącej ogniem górze unoszącej lawę, rozlewając ją po górskich płaszczyznach. Te ostatnie zjawiska są tylko bardziej widoczne i wpadają w oko niewnikliwego laika, podczas gdy polot myśli uczonego ogarnia nade wszystko całość, jedynie w tym, co powszechne [w oryginale: „das Ganze und Allgemeine”], skłonny widzieć wspaniałość, bo tylko ono zachowuje świat; to, co jednostkowe [w oryginale: „einseitig 〈jednostronne〉"] przemija i jego skutki po pewnym czasie są ledwo widoczne ${ }^{15}$.

To, co wielkie, nie objawia niczego, czego nie można by było odnaleźć już w tym, co małe. Tu leży sedno sprawy. Stifterowi chodzi o spojrzenie niemal badawcze na "całość" i na „to, co powszechne”16, małowymiarowe zaś - tak brzmi implicytny

Zob. Erhaben, das Erhabene. Hasło w: Historisches Wörterbuch der Philosophie. Hrsg. J. Rit ter. T. 2. Basel-Stuttgart 1972, s. 627-630. 
argument - jest spowinowacone $\mathrm{z}$ ową całością i powszechnością, a więc $\mathrm{z}$ „łagodnym prawem”. Dlatego też ogniwa enumeracji („Das Wehen der Luft das Rieseln des Wassers das Wachsen der Getreide das Wogen des Meeres das Grünen der Erde das Glänzen des Himmels das Schimmern der Gestirne"17) sa wyliczane - według charakterystycznej dla Stiftera licencji poetyckiej - bez przecinków, jakby legato, w przeciwieństwie do zjawisk wzniosłych, które sa poddane interpunkcyjnej poprawności. Przez wielkość tego, co małe, pisarz nie rozumie efemerycznych rzeczy codzienności, lecz żywość rzeczy w ogóle, czy bardziej „pneumatycznie” ujmując: ich oddech ${ }^{18}$. Dlatego cierpliwe zajęcie się zjawiskami małymi umożliwia przybliżenie - naukowe oraz artystyczne - do powszechności. Tymczasem ta ostatnia pozostaje niewyrażalna. Jak powiada Stifter, „uczeni na swoich warsztatach moga przedstawić tylko to, co jednostkowe, gdyż ukazanie ogółu równałoby się stwarzaniu świata” 19 . Niezależnie od tego, czy weźmiemy owe „warsztaty” dosłownie czy metaforycznie (jako swoiste laboratoria pisania), jasne jest, że do ich ograniczonej przestrzeni pasuje wyłącznie to, co małe.

To, co małe, ma zatem dwie zalety, których brak temu, co wielkie. Pierwsza w pewnym sensie „scjentyczna” - dotyczy wymiaru; to, co małe, jest łatwiejsze do badania niż wielkie fenomeny, które wykraczają poza ramy „warsztatów” i odwodzą obserwatora od istoty rzeczy. Unaocznia to porównanie mleka $z$ lawą ${ }^{20}$. Możemy mówić o decyzji na rzecz małej skali na niekorzyść wzniosłości z perspektywy naukowo-eksperymentalnej. Druga zaleta tego, co małe, ma bardziej podstawowy charakter. Podczas gdy pierwsza wiąże się z ilościową obserwacją przyrody, druga niejako „mistyczna” - jest jakościowa, dotyczy bowiem intymnego połączenia tego, co małe, $z$ „łagodnym prawem”. Według Stiftera to w zielenieniu się ziemi, a nie w jej trzęsieniu, wyraża się całość i powszechność, choć za każdym razem tylko w ,jednostkowej” formie.

\section{Mała ziemia chrześcijańskiego uniwersalizmu}

W tekstach Norwida z 1851 roku zdają się gromadzić motywy zmiany skali, które unaoczniają jego wyostrzoną wrażliwość na dynamikę między „wielkim” a „małym”. Podaję kilka przykładów. We fragmencie Promethidiona poświęconym realizacji myśli czytamy: „Kto kocha - małe temu ogromnieje / I lada promyk zolbrzymia nadzieje" (PW-3 443). Mowa tu o dążeniu do wielkości jako właściwej treści tego, co małe, jednocześnie zaobserwować można przynajmniej ironiczną wizję wielkości

Stifter, Vorrede, s. 10.

Przedmowa Stiftera, choć nie zawiera argumentacji teologicznej, nawiązuje do Biblii, mianowicie do Pierwszej Księgi Królewskiej (19, 11-13). Przez stopniowe wykluczanie wzniosłych zjawisk przyrody uwaga Eliasza zostaje zwrócona na zjawisko ciche, niepozorne. Dopiero wówczas prorok zaczyna słyszeć ducha Bożego czy oddech Boży. Zob. M a z u r, op. cit., s. 29-30.

S tif t e r, Przedmowa do tomu opowiadań „Kolorowe kamienie”, s. 21.

Warto przypomnieć fragment z Rzeczy o wolności słowa, w którym Norwid nazywa Mickiewiczowskie Księgi narodu polskiego i pielgrzymstwa polskiego „arcypotężnym zjawiskiem” i zestawia je $\mathrm{z}$ „wielkim natchnieniem wulkanu”. To wulkaniczno-erupcyjne natchnienie, które trzęsie „harfę nerwów”, poeta kojarzy z cichym, równomiernym tokiem Nilu: „Majestatycznym bywa niemniej od wulkanu" (PW-3 606-607). 
(„ogromnienia”, „olbrzymienia”). Paralela ze Stifterowskim przewartościowaniem jest oczywista. W wierszu Epos-nasza z kolei chodzi o naszych potomków, którzy „szczęśni tacy i ogromni” - będą się śmiali, spoglądając wstecz na swoich „małych” przodków, czyli na nas („że my tacy mali”, PW-1 159), co będzie rodzajem złudzenia optycznego. Wreszcie w traktacie Stowo i litera Norwid zarzuca architekturze rzymskiej, że wynika ona z grubiańskiego „z-ogromnienia” architektury greckiej. W zwrocie o „podniesieniu do ogromności niewłaściwej” (PW-6 325) Norwid jawi się jako poeta proporcji, zbliżony do Stifterowskiego umiaru (,Mäßigung”) estetycznego oraz etycznego ${ }^{21}$.

Co istotne, ani polski, ani austriacki twórca nie wyznawali kultu „małego” jako takiego. Wypada zauważyć paradoks: to, co małe, dla obu stanowi ostatecznie najbardziej stosowne medium właśnie wielkości, a więc powszechności. Chyba bardziej w przypadku Norwida niż Stiftera, ale potrzebne jest zastrzeżenie: to, co małe, nie wtapia się automatycznie w wymiar tego, co wielkie. Musi ono w niezwykłym wysiłku aktywnie uzyskiwać wielkość.

Jak chcę pokazać, Norwidowską drogę pomniejszenia - zamiast zaprzeczenia czy uwewnętrznienia - romantycznego czynu, można opisywać za pomocą dwóch zasad, które wyróżniłem w przedmowie Stiftera. Owymi zasadami sa, przypomnę, (ilościowa) praktyczność i (jakościowa) prawdziwość tego, co małe. Przyjrzyjmy się najpierw późniejszemu przypadkowi, $z$ drugiej połowy lat pięćdziesiątych XIX wieku. Chodzi o „wielkie” i „małe” w odniesieniu do chrześcijaństwa. Jak wiadomo, w poemacie Quidam, którego akcja toczy się za rządów cesarza Hadriana, nowa religia triumfuje w sposób cichy, jest to w pewnym sensie triumf niewidziany i nieusłyszany. Ten paradoks nie zaznacza się otwarcie w Quidamie, ale wynika $z$ występujących tam nielicznych i raczej marginalnych wzmianek o chrześcijanach. Expressis verbis Norwid rozwijał myśl o chrześcijaństwie jako zwycięstwie tego, co małe, w innym miejscu. W jednym $z$ epizodów Białych kwiatów (1856-1857) narrator relacjonuje swoje spotkanie $z$ mężczyzną „izraelskiego wyznania” podczas podróży transatlantyckiej. Ten „światły człek” uczył go hebrajskiego alfabetu, korzystając z przekładu Nowego Testamentu. Za sprawą lektury Biblii, inspirując się otoczeniem (bezkresem oceanu), narrator wspomina cud chodzenia po wodzie: „Przypominasz sobie zapewne moment i okoliczność, w których Pan przez morze szedł" (PW-6 199). Narratorowi zależy na tym, aby cud (Mt 14, 25-27; Mk 6, 48-50; J 6, 19-21) wyjaśnić niechrześcijańskiemu rozmówcy w sposób ścisły. Zaczyna on od zauważenia, że Chrystus szedł po wodzie dopiero w momencie, kiedy już - kuszony przez Szatana - zrezygnował z władzy ziemskiej (Mt 4, 8-10; Łk 4, 5-8). Narrator kontynuuje rozważania następująco:

$\mathrm{w}$ takim to położeniu raz przez powierzchnię morza szedł... akt był logicznie naturalny, wynikł z rzeczy samej, jeżeli, jako widzisz, na maleńkiej zi emi syryjskiej zostawszy Panem, to wystarczyło już, aby panem oto był w s z e c h zi e m - tam więc, gdzie owa ziemia maleńka, kończyła się też i cała ziemia z lądami swymi, a zaczynało się morze... Powiesz mi (lubo filozof jesteś): „A czemu to tak nie pójdziesz, bracie, aby pokazać mi, że takjest?" - Zmierz-że pierwej proporcję moją do Pana mego, tudzież uważ, azali on, aby pokazać to, czynił tee sprawę, czy nie raczej, aby ukryć dostojność swą... [PW-6 199] 
Co się dzieje w tej dziwnej, jakby nadmiernie logicznej argumentacji? Opiera się ona na przesłance teologicznej, a mianowicie tej, że Chrystus, choć zrezygnował z ziemskiej władzy, jest Panem o dwóch naturach - Boskiej i ludzkiej. Owa rezygnacja upoważnia go jeszcze bardziej do władzy duchowej nad wszechświatem. Przejdźmy więc do omówienia tego, co w tekście Norwida małe, czy dokładniej „maleńkie”. Wcielenie Boga zdarzyło się na małej, peryferyjnej ziemi w niezwykle skromny sposób. W tym właśnie miejscu wtrąca się narrator: skoro tak limitowana przestrzeń wystarczyła Bogu, żeby przyjść na ziemię, to w tym wybranym przezeń małym obszarze wszelka boskość musi znaleźć miejsce, a wszelka prawdziwa władza - zawrzeć się w jego granicach. Jeśli zatem Bóg zdecydował się na tak małe pole działania, to po prostu nie może być już żadnej sfery poza tą ograniczona dziedziną, gdyż Bóg nie przestaje być Bogiem w dobrowolnym pomniejszeniu. Wówczas następuje trzeci krok argumentacji: co oznacza ów paradoks dla cudu - tyleż sensacyjnego, co cichego - chodzenia po wodzie? Norwid definiuje „morze” jako sferę poza upowszechnioną Chrystusowa „maleńkością". Precyzyjnie kwestia będzie więc brzmiała: jak reaguje Chrystus, gdy spotyka się z granica, która z punktu widzenia jego wszechmocy nie istnieje? Reaguje „czyniąc tę sprawę”, która pozwala mu być niezauważalnym. Mianowicie czyni z morza zwykły teren, jak gdyby należało ono jeszcze do Jego „małej ziemi”. Nie chodzi o demonstrację władzy, lecz przeciwnie - o gest skromności. Obowiązuje bowiem paradoksalna zasada: im mniej coś jest natarczywe, tym bardziej jest Boskie. Niezwykle trafnie ową logikę wyraża epitafium św. Ignacego Loyoli, które stanowi motto powieści Friedricha Hölderlina Hyperion (1799): „Non coerceri maximo, contineri minimo, divinum est [Nie będąc ograniczonym przez największe, być objętym w najmniejszym, jest rzeczą Boska]”22.

W Ewangelii wedtug świętego Mateusza $(14,33)$ cudowny czyn chodzenia po wodzie potwierdza boskość Chrystusa. Norwidowski narrator w Białych kwiatach nie neguje, rzecz jasna, tego znaczenia cudu. Będąc wyraźnym paradoksalista, podkreśla natomiast inny aspekt sprawy, mianowicie Jezus udowodnia $\mathrm{w}$ taki sposób przede wszystkim swoje czyste człowieczeństwo. W jego człowieczeństwie boskość jest otwartą tajemnica. Wzniosłe skądinąd chodzenie po wodzie staje się aktem wkroczenia wielkości i bezkresu w to, co „maleńkie”. Wielkość czynu polega zatem na spontanicznej ekspansji tej maleńkości bez jej porzucenia. Chrystus improwizuje rzecz najprostszą, bezszelestnie idąc dalej. Rozmówca Norwidowskiego bohatera rozumie go chyba bardzo dokładnie, skoro kwituje egzegetyczny wywód towarzysza podróży takimi oto słowy: „To jedno ci powiem [...] że jużci Chrystus wasz był to może najidealniejszy człowiek..." (PW-6 200).

Epizod ten, typowy dla zawiłego Norwidowskiego stylu myślowego, pokazuje pomniejszenie nie tyle jako chwyt $\mathrm{z}$ warsztatu poety, ile jako kategorię teologiczną. W przytoczonym fragmencie nie chodzi o poetyckie wyobrażenie czynu wyzwoleńczego w XIX-wiecznej Polsce, lecz o cudotwórczość Chrystusa. Jest to jednak zabieg pełen doniosłości artystycznej. Uogólniając, możemy powiedzieć, że Norwid sprowadza wielkość - cud - w wymiar tego, co małe, i w taki sposób udostępnia go dys- 
kursywnie, a zarazem pomnaża jego tajemniczość. Pod tym względem pomniejszenie spełnia w tekście obie funkcje, zarówno „scjentyczna”, jak i „mistyczną”. Duchowa „wszechmoc” - która traktuje Norwid w zupełnie odmiennym kontekście i stylu - okazuje się siłą współmierną z „łagodnym prawem” opisanym przez Stiftera.

\section{Koło prototypem czynu}

Szereg przypadków pomniejszenia w dziele Norwida zaliczałbym raczej do typu „scjentycznego", czyli przypisywałbym im funkcję sprowadzania obserwacji do Stifterowskich „warsztatów” (co zresztą nie znaczy, że funkcja „mistyczna” musi być im obca). Sądzę, że na szczególną uwagę w tym kontekście zasługuje fenomen geometryzacji w utworach autora Rzeczy o wolności słowa. Zainteresowanie myśla abstrakcyjną oraz przedstawieniami przestrzeni przewija się przez całą twórczość Norwida. Świadomość figur geometrycznych demonstruja jego obszerne refleksje w historyczno-etnograficznym traktacie Prototypy formy (1851): „piramida - kwadrat - koło - elipsoida - prostopadła" (PW-6 299) ${ }^{23}$. W tej części będę omawiał jedna $\mathrm{z}$ owych form podstawowych, mianowicie koło. Norwid wprowadza koło w ramach teorii „aktu”, ta forma jest więc u niego ściśle związana $z$ tematem pomniejszonego aktywizmu. Co więcej, w różnych reprezentacjach koła wybrzmiewają wyraziste wzmianki dotyczące zakreślania, odgradzania, ograniczania, a więc - by tak to nazwać - praktyk „redukcji”, o które mi tutaj chodzi. Wszak Stifter redukuje wybuch wulkanu do wylewającego się mleka (sprowadzając zjawisko do „warsztatu”, którym jest kuchnia). Narrator transatlantyckiego epizodu z Białych kwiatów objaśnia z kolei, jak Bóg ograniczył się dobrowolnie do „małej ziemi”.

Koło we wspomnianym traktacie (w rozdziale $O$ pojęciu koła) okazuje się przede wszystkim najprostszym zapisem aktu:

Koła nie ma bez aktu - koło jest skutkiem aktu.

Koło jest pierwszą formą, przez którą forma w ruch przechodzi.

Koło narysowane na papierze uważać by można jak leżące na płask koło wozu - to już rzecz kolista, a nie koło. Leży ono i nie porusza się dlatego, dlaczego i arkusz papieru na ścianie przylepiony nie porusza się również. Wszakże, gdybyś je postawił tak jak koło, okazałoby zaraz najwidoczniej, że w nim ruch a forma nierozdzielne. Koło bowiem, skutkiem aktu będąc, oddziaływa swą formą. Wszelkie koło w naturze spotykane, nie wyjmując formy świata tego, uważane być musi tym sposobem. Obieg globu jest również skutkiem aktu na początku aktów w myśli BOŻEJ! [PW-6 302]

Koło staje się kwintesencją czegoś, co zostało wytworzone. Tej skromnej, choć może nieoczywistej tezie sprzyja fakt, że „koło” ma w języku polskim podwójne znaczenie. Ruch, wyrażający się tutaj w obiegu Ziemi, stanowi jak gdyby część koła. Jednakże akt, który go uruchamia, działa według tego modelu również wówczas, kiedy chodzi o najprostsze koło, zaledwie narysowane. Może to zilustrować rysunek dziecięcy: nieopanowane pociagniecie daje się w nim odczytać jak rodzaj podpisu czy dowodu, że coś naprawdę zostało uczynione; widzimy żywy, niezaprzeczalny ślad pewnego ruchu - właśnie w taki sam sposób, jak obieg Ziemi udowadnia, że Bóg jest principium wszelkiego ruchu. 
Te rozważania są mniej abstrakcyjne i mniej arbitralne, niż mogłoby się wydawać. Nieunikniona językowo asocjacja koła geometrycznego z kołem mechanicznym ma bowiem dodatkowe implikacje. W kontekście polskiej historii kulturowej prowadzi do postaci Piasta Kołodzieja, do którego według legendy należy wynalazek tzw. koła promiennego, które w IX wieku wyparło koło pełne (Dodatek. Piast i jego rewolucja). Dla Norwida koło dzięki owej innowacji może stać się modelem tego, co napędza Polskę jako naród. Szereg asocjacyjny nie kończy się na tym. Koło promienne Piasta Kołodzieja - zaprezentowane przez Norwida jako znak wysokiego potencjału cywilizacyjnego Polski (PW-6 304) - zmienia się na końcu Promethidiona w model tego, jak należy rozumieć instytucję „wieszcza”. Niewątpliwie zwracając się przeciwko Mickiewiczowi i jego transgresyjnemu profetyzmowi, rozmówca dialogu Wiesław przedstawia wieszcza jako kontemplatora luk, a przez to granic. Przy tym Norwidowi zależy na skrupulatnym rozróżnieniu kategorii proroka i wieszcza, gdyż w „mistycznym” romantyzmie Mickiewicza dostrzega on niebezpieczeństwo pomylenia tych ról. Inaczej niż prorok religijny, który nazywa swe przedmioty absolutnie, wieszcz poetycki ma być artysta „przeciwności”. Jego podstawowa działalność polega na tym, że „Określa profil...”. Jest zatem porównywalny do kogoś, kto trzyma wycinankę skierowaną na niebo i przez wycięte fragmenty spostrzega „plejadę” „błękitnej prawdy”. Prorok zaś kieruje się bezpośrednio do „części istotnej", czyli do pozytywu; żadnego negatywu nie potrzebuje (PW-3 456). Omawiam tę drobiazgowa dystynkcję, bo stanowi ona niezbędny kontekst dla modelu koła w Promethidionie. Wiesław o „akcie” kreślenia mówi następująco:

Tu kredą koło zakreślił na stole,

A potem z środka promień wywiódł w kole

I mówił:

- Ś rodek, który centrum znaczy,

Znaczy i sposób w tym polskim języku,

Który ma w sobie i w ludziach słuchaczy -

Owóż to jeden sposób! - O! Mistyku

Największy, Piaście stary, tyś to wiedział

Od złotowłosych pielgrzymów zza świata...

. . . . .

Tu zamilkł - potem rzekł: Ta cała krata

Promieni, w for my strzelających przedział,

To sa prorocze wnętrzności narodu,

A wieszczów wieniec - to linia obwodu,

A wnętrzny koła a st r, skąd są promienie,

To przenajczystsze narodu sumienie! [PW-3 457]

Norwid przy różnych okazjach wskazuje na podwójne znaczenie leksemu „środek" ('centrum' oraz 'medium') ${ }^{24}$, często w związku $z$ inną figurą geometryczną, mianowicie z krzyżem, który w jego tekstach właśnie ma być środkiem-medium, by realizować środek-centrum - skrzyżowanie poziomu i pionu. Do tego ważnego w myśleniu estetycznym Norwida motywu jeszcze wrócę. W przytoczonym fragmen-

24 Zob. M. Inglot, Duch i litera (refleksyjny kształt poezji Cypriana Norwida). W zb.: „Dramat życia prawdę wyrabiajacy”. Materiały norwidowskiej sesji naukowej (Jelenia Góra, 6-7 maja 1983). Red. M. In glot. Wrocław 1985, s. 19. 
cie Promethidiona rozmówca Wiesław niejako podkreśla, że dzięki wynalazkowi Piasta Kołodzieja środek koła (centrum) stał się najpierw jego mechaniczną osią, a później środkiem-medium ruchu („komunikacji”) (PW-6 299). Zgodnie z rysunkiem linie radialne w kole, analogicznie jak w kole promiennym, mamy sobie wyobrażać w rotacji. Wówczas Wiesław komentuje swój piktogram w spekulacyjnej egzaltacji: promienie to „prorocze wnętrze” narodu polskiego, koło zaś - „wieniec wieszczów”. Proroctwo zatem staje się istotą narodowości (tradycji narodowej, mającej wynikać z sumienia), podczas gdy instytucja wieszcza ogranicza się do pewnej funkcji granicznej. Transgresyjnemu rozumieniu twórczości przeciwstawia się w taki sposób ideę limitacji. Im wyraźniejsza granica, tym wyższa nagroda - mowa przecież o laurze poety jako „obwodzie”.

Norwid zdaje się argumentować również politycznie, gdyż kilka wersetów niżej Wiesław powiada: „O Polsko! granic twych nie widzę linii, / Nic nie masz oprócz głosu - tak uboga!" (PW-3 459). Oto zarzut: Polska jest fantastyczną rzeczywistością mityczną, która nie zna samej siebie i nie jest zdolna do autodefinicji, a więc i do autonomii. „Głos” możemy odczytać różnie; chyba nie będzie niedorzeczne rozumienie, wedle którego to ponowna aluzja do „proroctwa” Mickiewicza. Wówczas przesunięcie proroctwa do „wnętrza” narodu (promienie koła) byłoby równoznaczne $\mathrm{z}$ symbolicznym wywłaszczeniem Mickiewicza, a nowy program brzmiałby: Polska już „promieniuje”, poeta ma wyłącznie zapewniać konturowanie czy nakładać negatyw. Jeśli Polska chce zyskać polityczną oraz społeczna pewność siebie, potrzebuje ścisłości (której, rzecz jasna, w sensie administracyjnym nie mogła wtedy posiadać z powodu rozbiorów). Poeta - jako „linia obwodu” - jest powołany przede wszystkim do bycia swoistym stróżem czy może też narzędnikiem małej skali narodowej.

Ta formuła pokazuje Norwida w niezwykle antyromantycznym świetle. W rzeczywistości idzie tu o takie pojęcie „małego”, którego właśnie nie należy rozumieć $\mathrm{w}$ sensie ograniczającym czy zawężającym. Mamy raczej do czynienia $z$ odwrotną proporcjonalnością, jak w przedmowie Stiftera i w transatlantyckim epizodzie z Białych kwiatów Norwida. Według tej logiki to, co małe, wiąże bliskie - choć nie od razu zauważalne, nie wybijające się na czoło - powinowactwo $z$ ogółem, a więc z powszechnością, której brakuje zjawiskom wzniosłym, tym pozornie „wielkim”. To, co małe, łatwiej wpisuje się w całość niż wszelka erupcja w skali wielkiej. Bóg objawił się na „małej ziemi”, urodził się - dodać można - w postaci delikatnego dziecka. To właśnie mała skala Objawienia ma udowadniać nieograniczoną władzę duchową. Wspomnijmy poetycko-teologiczną egzegezę owego zdarzenia: chodzenie po wodzie oznacza, że w obliczu wielkości - bezgranicznego morza otaczającego statek - Jezus pozostaje wędrowcem, którym był na „małej ziemi”. Model koła z Promethidiona ma homologiczną strukturę. Wieszcz obwodzi Polskę ścisłą granica. Profiluje i tym samym pomniejsza kraj w obliczu jego niejasnego statusu, by dopiero wtedy przydać mu cechę powszechną. $Z$ pierwszej części Promethidiona pochodzą słynne wersy: „I tak ja widzę przyszłą w Polsce sztukę, / Jako c h o r ągiew na prac ludzkich wieży" (PW-3 446). Na pewno nie jest przypadkowe to, że Polska już tutaj pojawia się w postaci figury geometrycznej, w skali małej - zmniejszona do emblematu.

Zastanowić się można, jaka antropologia wynika z tej dynamiki abstrakcyjnej. 
Zdaje się przecież posiadać wyraźny wymiar zabijający konkretność życia, w którym kompresję sensu ocenia się wyżej niż jego swobodne rozwinięcie. W tym kontekście trzeba sobie uświadomić, co stanowiło początek Norwidowskiej koncepcji koła: miało ono być „skutkiem aktu”. Otóż nie jest to dynamizacja wyłącznie mechaniczna, lecz w pewnym sensie też personalizująca, gdyż wątek dynamiczny wiąże się jak widzieliśmy $-z$ „mistykiem największym”, Piastem Kołodziejem ${ }^{25}$. W figurze krzyża również kryje się wątek dynamiczny, skoro Norwid postrzega krzyż nie jako skończony emblemat, ale jako wyzwanie rzucone jednostce, by we wszystkim szukała ona skrzyżowania immanencji i transcendencji. Jest on zatem bardziej radykalną figura myśli niż koło, gdyż pozwala nie tyle na pojmowanie skomplikowanego organizmu w praktycznej małej skali, ile w sposób jeszcze prostszy unaocznia ideał zupełnej koincydencji. Nie zaskakuje więc, że Norwid zrewidował swoje rozważania dotyczace prototypu koła, i to w stosunkowo widocznym miejscu, mianowicie w wykładach o Juliuszu Słowackim (1860). Starał się tam uzupełnić teorię profilu, negatywu i linii obwodu, którą sformułował 10 lat wcześniej. W perspektywie egzystencjalnej - zamiast narodowo-kulturowej oraz literacko-politycznej stawiał pytanie o podmiot. W wykładzie czwartym czytamy:

Najwygodniej być ukształconym: człowiek wtedy ma horyzont ducha pewny, zakreślony i skończony, jako posag w formie bezjegowolnie wpierw zrobionej odlany; stan taki Włosi określają wyrazem tondo, a Rosjanie dobitnie i malowniczo wyrazem krugom. Jeden i drugi wyraz, tondo i krugom, znacza o krą gły, czyli - jako ujemna forma posagu - zwypadkowany bez-własnowolnie różnymi naciskami zewnętrznymi... Tak to byli niewolnicy rzymscy aż do dni Spartakusa, który gwałtem i krwia poprzedził oliwne słowa Chrystusowe. Ale człowiek, co w kręgu tym duchem nie zamieszkał, lecz tylko przeszedł pod nim, jak pod tryumfalnym łukiem, [...] człowiek taki jest kształcacy się, nie okragły, i owszem, ciągle wyokraglający się współ-dzielnie. [...] Żeby zatem korzystać z cywilizacji, trzeba nie być jej samym tylko logarytmem [...]. Jeżeli człowiek tak ukształcony jest to człowiek spotkany, i gdyby tak pozostał, byłby homunkulusem przez doktora Fausta w retorcie szklannej zrobionym. [PW-6 432]

Można odnieść wrażenie, że Norwid nabrał wątpliwości co do własnej koncepcji wpisywania „proroczego wnętrza” w figurę koła. Realistycznie rzecz ujmując przykłady Starego Rzymu oraz „anonimowego” wieku XIX to podkreślaja - wypada przyjąć model ciągłej wzajemnej deformacji na poziomie społecznym. Wówczas koło jako organiczny symbol wspólnoty unieważnia się, wręcz pęka. W skorygowanej wersji myślenia kołem z 1860 roku to przez społeczeństwo każdej jednostce udziela się jej „koło” i w tych kołach wszyscy niejako będą zamykani; w pewnym sensie koło organicznej całości, znajdując się w harmonicznej rotacji, przetwarza się w wielość anonimowych monad. Remedium zaproponowane przez poetę nie wydaje się konkretne, polega bowiem zaledwie na wariacji - a zatem kontynuacji - dotychczasowej metaforyki: „linia obwodu” miejsca społecznego nie powinna być do końca narysowana, by koło społeczeństwa pozostawało otwarte. Chodzi, jak widać,

W bardziej kosmicznym wymiarze mistyczna wizja Piasta i formy koła powróci w strofie 5 Fortepianu Szopena (PW-2 144):

I była w tym Polska, od zenitu

Wszechdoskonałości dziejów

Wzięta, tęczą zachwytu --

Polska-przemienionych kołodziejów!

Zob. też strofę 10 (PW-2 147). 
o obraz minimalnego pola działania wewnątrz struktury społecznej - w „kościele międzyludzkim", jak można by powiedzieć za Witoldem Gombrowiczem ${ }^{26}$. W każdym razie perspektywa całkowicie się zmieniła. Szczególnie doniosła w naszym kontekście wydaje się figura homunkulusa jako człowieka par excellence niewolnego, bo „zrobionego”, ukształtowanego przez czynniki zewnętrzne. Homunkulus w ograniczającej retorcie jest straszliwą wizją przejęcia władzy przez naukę właśnie za pomocą warsztatowego pomniejszenia jako narzędzia dominacji. To niebezpieczeństwo zmiany skali daje się może najlepiej zrozumieć w opozycji do Chrystusa na „małej ziemi”: Bóg - jak widzieliśmy - zmniejszył się i przez to przywrócił wielkość temu, co małe. Homunkulus jest, przeciwnie, obrazem sztucznego i samowolnego wytwarzania małego, a zatem wyrazistym przypadkiem takiego pomniejszenia, które najzupełniej odcina małowymiarowe od uprzywilejowanego powinowactwa $z$ powszechnością i całością.

Nawet jeśli można mówić metaforycznie o „laboratorium” poetyckim Norwida, i to w odniesieniu do wszystkich okresów jego twórczości, nie wolno zapominać, że poeta rozumie pomniejszenie jako zdolność wewnętrzną, nie dającą się wytwarzać technicznie. Dlatego też komparatystyczne zbliżenie ze współczesną mu biedermeierowską myślą Stiftera okazuje się wysoce uzasadnione i pouczające.

\section{Czyn ze słowa? Mikrointerwencje przeciwko magii słów}

Trzeci przypadek, który omówię, wynika z problematycznej relacji czynu i słowa. W komentarzach do późnoromantycznych apologii czynu z około 1850 roku Norwid używa gorzko-ironicznych, ale całkiem poważnych chwytów pomniejszenia. Autor Promethidiona współpracował wówczas z dziennikiem „Goniec Polski”, który ukazywał się w latach 1850-1851. Był na jego łamach atakowany przez innych współpracowników pisma; Juliusz Wiktor Gomulicki określał te diatryby przeciwko Norwidowi mianem „prostackich złośliwości” (PW-11 626). Poeta wnikliwie czytał przyczynki na swój temat; każdy z nich skłaniał go do ponownych autodeklaracji. W lutym 1851 dziennikarz Emilian Marian Pol opublikował jedną ze swoich ,gawęd listowych". Pisał w niej:

jeżelić „czynu nam trzeba, nic więcej jak czynu”, to ten czyn z sło w a się wykłuje, a szczep Sło wia n jest powołany tą słowa potęgą zawładnąć, jako król-naród ongi ostrzem miecza władał. Lecz cisza głucha koło mistrzów Słowa; zdają się oczekiwać - kogóż? zapytuję się $[\ldots]^{27}$.

Chociaż Norwid nie stanowi przedmiotu owej polemiki, przeciwnie, jest wspominany pozytywnie (zwłaszcza jego wiersz Vendôme z 1849 roku), diagnoza Pola o niezrozumiałym „czekaniu” wielkich poetów sprowokowała twórcę do obszernej repliki. Nie była to rewindykacja nowego aktywizmu jako taka, której Norwid na-

W. G o mbrow i c z, Ślub. W: Transatlantyk. -Ślub. Zkomentarzem autora. Warszawa 1957, s. 125. Zob. M. Ma słow s ki, „Kościót międzyludzki” $w$ „Ślubie” Witolda Gombrowicza. „Teksty Drugie” 1999, nr 1/2. O Norwidzie i Gombrowiczu zob. J. Trzn a d el, Czytanie Norwida. Próby. Warszawa 1978, s. 198-207. - S. S a wi c ki, Norwida walka z forma. W: Norwida walka z forma. Warszawa 1986, s. 19-23.

E. M. P o 1, Gawędy listowe III. „Goniec Polski” 1851, nr 43, z 21 II, s. 1. 
trętnie zaprzeczał. Przecież sam antycypował zwrot „czynny” w literaturze polskiej w bliskiej przyszłości. A więc to, że Pol przez hasło „czynu nam trzeba, nic więcej jak czynu” powołał się na przedstawiciela skonwencjonalizowanej poetyki tyrteistycznej - Piotra Dahlmana ${ }^{28}$, chyba nie jest problemem per se. Norwid bowiem nie tylko sam zdradzał tendencje tyrteistyczne na początku lat czterdziestych XIX wieku - gotów był też zachowywać w poezji retorykę pobudzenia do czynu co najmniej do roku 1850 czy nawet do lat pięćdziesiątych. Kamieniem obrazy była raczej konkretna koncepcja Pola, założenie automatycznej relacji między czynem a słowem. W „Gońcu Polskim” z 8 III 1851 Norwid pisał:

Mówisz, że c zyn u trzeba przede wszystkim, c zyn u, o! Emilianie, do którego jak do Dantejskiej jakiej istoty się odzywam, z powodu iż nie wiem, ktoś jest i co zacz? [...] Owóż, czynu, powiadasz; a toć półtora roku leżał tam rękopism o literaturze czynu, choć bez różnic wyraźnie okazanych od literatury bezczynnej, co autor na później zachował sobie.

Tak jest; tylko widzisz, o! Emilianie, że sam twierdzisz, iż czyn z słow a pochodzi; owóż należałoby najprzód literaturę czynu od literatury bezczynnej wyróżnić...

(Pót-listu. 〈Przez autora wierszy częstochowskich). PW-6 381)

Przez porównanie Pola z postacią z Boskiej Komedii Norwid daje chyba wyraz pewnej waloryzacji czynu. Jednocześnie sygnalizuje przez tę asocjację, że „czyn” należy choćby częściowo do świata mitycznego, a może nawet „infernalnego”. Pyta więc, co się wygrywa, gdy quasi-mityczne pojęcie czynu w dodatku „wywija” się „ze słowa" (PW-6 381). Ryzyko niemal tautologiczne wydaje się oczywiste. W każdym razie mniej więcej magiczny paradygmat czynu musi uwzględnić sceptyczne pytanie o kryteria i tryb „aktywności” słowa. Przykład niezauważonego rękopisu o „literaturze czynu" - nawiązujący najprawdopodobniej do przedmowy do Niewoli z roku 1849 - to pokazuje: czy nie brak temu leżącemu rękopisowi czegoś takiego, czego sam jako „słowo” nie jest w stanie podejmować? Norwid ogranicza się do aluzji. Jeśli zaś wspomnimy ową przedmowę, to właśnie nieobecność instytucjonalnego kontekstu usprawiedliwia rozróżnienie między „literaturą czynu” a „literaturą nieczynną". Zarzut Norwida zdaje się zmierzać do tego, że czyn nigdy nie może zależeć wyłącznie od słowa, bo słowo nie jest zdolne wytwarzać sobie samemu warunków. Nie sposób przy tym pominąc faktu, iż niecały rok wcześniej poeta zdefiniował swoją twórczość jako swoistą działalność zamiast praktyki. W liście do Jana i Stanisława Egberta Koźmianów z lipca 1850 tak wyjaśnia rzekomą „nieestetyczność” swojego pisania:

Gdybym miał czas i sumienie wodą-słowa rozrabiać każdą myśl na tomy, to i pisma moje, i list każdy, i ten list brzmiałby donośniej, milej - obojętniej. Ale niech to nie zraża, dla Was wszystkich zawsze jednakie mam uczucie - szacunku i prawdy - tylko, że literatura, moim zdaniem, już jest, albo za chwilę będzie, musi być - tylko testamentem-czynu, więc zwykłem pis a ć to jedynie, czego zrobić nie mogę, inaczej bowiem ani jest użytecznie, ani estetycznie, naumyślnie walać się atramentem. [PW-8 98]

Ta postawa nieoczekiwanie zbliża się do maksymy Pola („czyn $z$ słowa się wykłuje”), o ile „czyn” w obu przypadkach stanowi horyzont literatury. W rzeczywistości zaś chodzi o pozycje przeciwstawne. Norwid bowiem zaprzecza, jakoby

28 M. Janion (Literatura i spisek. „Pamiętnik Literacki” 1976, z. 4, s. 61) pisze o „gruntownym kryzysie tyrteizmu" w owym okresie. 
emanacja czynu z literatury - w sensie automatycznego „wypływu” - była możliwa. Podkreśla natomiast najwyraźniejszy rozziew między nimi; pisanie okazuje się nieharmonijnym, pełnym niepokoju doświadczeniem dystansu od „robienia” (albo czynienia). Pod tym względem też nie jest do końca precyzyjne mówienie o „słowie jako substytucie czynu" w owym okresie twórczości Norwida ${ }^{29}$. Wprawdzie poeta dokonuje tej zamiany według kryteriów metaforycznych (a więc ekwiwalencji), ale ważniejsza zdaje się świadomość pozostawiającego braku, który podważa pisanie ze strony niemożliwego czynu („czego z robić nie mogę). Słuszniej bodaj byłoby mówić o ofierze składanej czynowi przez „pisanie piękne”. Trzeźwe przyjęcie braku ma ugruntować nową estetykę. Norwid doprowadza tę ideę aż do wniosku, iż pisanie piękne bez ofiary właściwie zatraciłoby swoją piękność (,ani jest użytecznie, ani estetycznie”). Tak chyba należy rozumieć uwagę o „testamencie”: poeta nieustannie pisze swój testament, a więc zarządzenie na czas po swojej śmierci, jak gdyby tu i teraz umierał. Bardziej znaną formułę o testamencie zawarł Norwid jednak gdzie indziej, rozwijając dodatkowy wymiar. Kilka miesięcy po napisaniu listu do braci Koźmianów i około miesiąca przed Pót-listem do Pola - a więc w styczniu 1851 w Paryżu ukazał się Promethidion. W epilogu do wierszowanego traktatu znajduje się słynny fragment:

Słowo - jest czynu te s ta men te m: czego się nie może czynem dopiać, to się w słowie te s tuje - przekazuje; takie tylko słowa są potrzebne i takie tylko zmartwychwstają czynem - wszelkie inne są mniej lub więcej uczoną frazeologią albo mechaniczną koniecznością, jeżeli nie rzeczą samej sztuki. [PW-3 463]

Przy całej powadze tematu i tonu Norwid przemycił do swojej koncepcji wysoce ludyczną etymologię poetycką, według której testament to nie tylko zarządzenie (ostatnia wola), ale też „testowanie”. Wrócimy jeszcze do tej figury w kontekście polemik na łamach „Gońca Polskiego”. Na razie możemy zauważyć, że w Promethidionie - bardziej niż w liście do Koźmianów - rozwinięty jest aspekt tanatopoetyczny. „Zmartwychwstanie czynem” przecież zakłada, że słowa również podczas „testowania" mają być martwe czy prawie martwe. Pisanie okazuje się w tym świetle istotnie ars moriendi. „Test” ma przynajmniej bezpośrednio etyczną implikację; oznacza dla odpowiedzialnego poety, że zamiast ślepego utwierdzenia aktu ma najpierw próbować swoja a ge n d ę na sobie samym ${ }^{30}$. Jak Norwid napisze w jednym ze swoich abolicjonistycznych wierszy (John Brown, 1863): „Co potem w dziejach, to czynicie pierwéj / Na samych sobie [...]” (PW-1 305).

Około 1850 roku Norwid ocenia „słowo” niezwykle negatywnie, co może wydawać się zdumiewające, jeśli wziąc pod uwagę, że jest on wybitnym sceptykiem „czynu”. Jego logika polega jednak na tym, że zarzuca on tyrteizmowi „f r a z e ol og i ę albo mechaniczną konieczność” i niedocenianie „umierania” słowa. Tyrteizm może być naiwny w swojej wyobraźni czynu - „ideologiczny” zaś jest dla Norwida w swej wierze w słowo. Pisał poeta w Pót-liście: „jak zaczniesz słowem (a nie

30 O dziele poetyckim jako „agendzie” - jak sądzę, właśnie w przeciwieństwie do „aktu” (czynu) wspomina C. Norwid w wierszu Do Walentego Pomiana Z. [...] (1859), stanowiącym epilog do Vade-mecum (PW-2 151). 
pieśnią) śpiewać, to jesteś ideolog i now a to r, a jak już dośpiewasz, to znów: "To nic now e go" - znów jesteś ni e n ow a t o r" (PW-6 382). Poetyka pobudzenia do czynu okazuje się oszustwem. Ujmując to samo w języku Promethidiona: miast trzymać się bezinteresownego „testowania”, tyrteizm udaje, jak gdyby był w stanie przeskoczyć fazę przygotowawczą. Ukrywa swoją martwotę, ale tylko póki trwa obecna interwencja słowem. Norwid w sposób prowokacyjny broni stanowiska (ludowej) „pieśni” przeciw tyrteizmowi. „Słowo” natomiast prawie kompletnie utożsamia z „martwą literą"31. Reagując na derywacje „Słowian” ze „słowa” przez Pola, poeta dodaje do listu wiersz Stowotwór ${ }^{32}$. Tak naprawdę dopiero tutaj wyjaśnia się Norwidowska intencja polemiczna. Chodzi mu o to, by w słowie odnaleźć boski logos, do którego zbliżać może się tylko milczenie. Wszelki literacko-aktywistyczny kult słowa okazuje się w obliczu tego wyższego słowa albo uzurpacją, albo upadkiem w płaskość „gotyckiej”, czyli pogańskiej litery:

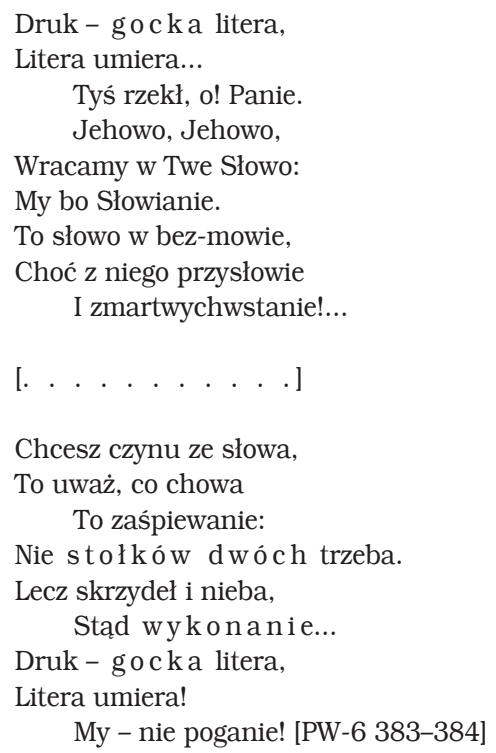

Rozumiem ten zwrot teologiczny oraz apologetyczny w polemice na tle wyraźnego etnocentryzmu w argumentacji Pola. „Słowianizacji” słowa przeciwstawia się spekulację o logosie, według której Słowianie nazywają się tak nie z powodu wrodzonego magicznego potencjału do czynu, lecz dlatego, że zależą od Słowa - drugiej osoby Trójcy ${ }^{33}$. Ale jeśli jako kryterium weźmiemy wiersz Stowotwór, to czym w ogóle może być zakres „testamentu”? „Skrzydło i niebo” (z ostatniej strofy Słowotworu)

To kolejny nieoczywisty chwyt, jeśli przypomnimy sobie bardziej znane fragmenty, zwłaszcza z Ducha i litery czy z Rzeczy o wolności słowa, gdzie „literę” waloryzuje się wobec „słowiańskiego” spirytualizmu. Zob. Ch. Zehnder, Apologia litery i lektura aktywizmu. Od Schlegla do Norwida. W zb.: Romantyk jako czytelnik. II Sympozjum im. Zofii Trojanowiczowej. Red. A. B o r kow s k a - Rychlewska, W. Ha merski, K. Trybús. Poznań 2020. ru”. „Pamiętnik Literacki” 1989, z. 4). 
po dokonanym przez artystę samoograniczeniu nie sa już przecież do dyspozycji. Poeta dostrzegając, jak bardzo ten wiersz usuwa mu grunt pod nogami, zmienia w ostatnich wersach - czy dokładniej dopiero w postscriptum - system referencyjny: „P.S. Jak raczysz zachować w pamięci tę piosnkę, cny Emilianie, to drugą połowę listu przeszlę... boć chcesz czynu ze słowa!" (PW-6 384). W tym zwrocie ku pragmatyce listu dydaktyzm jeszcze przybiera na sile. Norwid dosłownie zadaje Polowi lekcję do odrobienia. Obiecaną uczniowi nagrodą będzie druga połowa „pół-listu” (ten ciagg dalszy nie zaistniał, przynajmniej nie w postaci pisemnie zachowanej).

Mówienie o dialogu byłoby w przedstawionym kontekście na pewno eufemizmem. Ale oczekiwać tu dialogu byłoby właśnie pomyłka, gdyż wyrafinowanie owego postscriptum polega na tym, że poeta podejmuje gest pomniejszenia $\mathrm{w}$ momencie, kiedy właściwie jest już na to za późno. Rozumiemy, że przeczytaliśmy właśnie dopiero „pół-listu”. Pol, przetwarzany przez Norwida w prototyp czytelnika, ma najpierw spełnić minimalne wymogi poety - przede wszystkim ma wykazać chęć nauczenia się od Norwida, że magia słów świadczy o fałszywej świadomości artystycznej. Jeśli jest do tego gotowy, to $z$ autorytatywnego stanowiska poety okazuje się godny otrzymać druga połowę listu pocztą i przez to zyskać sposobność zrekonstruowania, jak „połowa” tekstu staje się całością.

Wciąż jednak odpowiedzi wymaga centralna kwestia - w którym $z$ etapów znajdziemy „czyn ze słowa”? W reakcji czytelniczej czy w obiecanym ciagu dalszym listu? Chyba nie jest to jednoznaczne. W każdym razie Norwid przez ten model recepcji naucza, że czyn wynika ze słowa nie automatycznie, ale wyłącznie pod specyficznymi warunkami, wśród których niezbędna jest współpraca czytelnika. Jeszcze ważniejsze wydaje się jednak to, że autor nie tylko pisze. Odpowiedzialnym twórca będzie dopiero wtedy, gdy pozostawi tekst na tyle otwarty, iż będzie on potrzebował aktywnego stanowiska z zewnątrz, czyli współdziałania ze strony czytelnika. Akt musi być możli w o ś c i ą tekstu, taką możliwością, którą nie sam tekst („litera umiera”), lecz tylko czytelnik będzie mógł wypełnić.

Memoriat o Młodej Emigracji (1850) zawiera wersję polityczną owego modelu. Aby słowo mogło stać się „aktywne”, musi być utwierdzone z zewnątrz: „To, co piszę - przed Bogiem piszę - i w tym jest a kt, że piszę - a kto chce te myśli wziąść i wcielić, daję słowo honoru, że skąd wyszły, zapomnę z radością" (PW-7 114). Można stąd chyba wnioskować, że im bardziej „wcielenie” leży poza zasięgiem poety, tym wyżej Norwid stawia odpowiedzialność tego, kto pracuje nad swoim „testamentem". Akt oznacza przeważnie otwieranie potencjału.

Wrócimy na koniec do „Gońca Polskiego”. W odróżnieniu od Pola, który poniekąd głęboko podziwiał autora Promethidiona, dziennikarz i poeta Władysław Dienheim-Chotomski miał dlań tylko kpinę. W serii felietonów Błędny ognik parodiował język i styl poetycki Norwida, zwłaszcza z wydanego niedawno Promethidiona. Najciekawsze wydaje się określenie tego stylu poetyckiego mianem „konceptyzmu” (concettismo) w pierwszym $\mathrm{z}$ felietonów Dienheima-Chotomskiego $\mathrm{z}$ lutego 1851, gdyż barokowy konceptyzm związany jest $\mathrm{z}$ powiększeniem rzeczy przez dalekie metafory ${ }^{34}$. Jednakże opinia ta nie doprowadziła dziennikarza do dyskusji pogłę-

34 W. Dien heim-Chot o m ski, Btędny ognik. (Artykulik salonowy). „Goniec Polski” 1851, nr 48, z 28 II, s. 2. 
bionej w zakresie poetyki (historycznej). W „Gońcu Polskim” dwa tygodnie później ukazało się nieubłagane odniesienie się Norwida do przyczynku publicystycznego; poeta zarzucał Dienheimowi-Chotomskiemu m.in. „przyrodzoną [...] ciemność”35. W tym samym okresie (7 III 1851) opublikował inną autodeklarację w postaci listu do Władysława Bentkowskiego ${ }^{36}$. W kontekście pomniejszonego czynu dokument ten wydaje się najbardziej frapujący. Norwid opisuje w nim, jak postępował, kiedy nie zgadzał się z działalnością publicystyczną anonimowego autora piszącego do krakowskiego „Czasu”:

Kiedy C. K. N. ciemności momenta w korespondencie „Czasu” spostrzegł - wycięte druki i naklejone Redakcji przesłał - ubolewał - przyczyny okazywał, rad udzielił. Nie skomponował on ani jednego słowa na karb korespondenta - nie drwił - na piśmie Redakcji prosił, aby imię jego podpisano, iżby w osobie swej zato sprostowanie ucierpiał. Chcecie czynu ze słowa - oto macie!

(,Ostatnie stowo to nie sa litery”. PW-6 603)

Strukturalna różnica w stosunku do Pót-listu - przy całej bliskości co do moralizmu - polega na tym, że tutaj nie chodzi o pisarstwo Norwida. Poeta występuje jako czytelnik, inscenizuje się wręcz jako idealny, tyleż uważny, co wyrozumiały czytelnik, który nie waha się wyciagać maksymalnych konsekwencji z lektury. Patos tej postawy jest $\mathrm{z}$ kolei ofiarny. Podczas gdy w Memoriale o Młodej Emigracji poeta wyrażał gotowość rezygnacji z praw autorskich, jeśli tylko jego program znajdzie „wcielenie”, to tutaj - jako idealny czytelnik - ofiaruje swoje autorstwo, by umożliwić poprawkę cudzego błędu. Ten chyba niesprawdzalny epizod jest wysoce nieprawdopodobny dlatego, że ofiara zakłada rodzaj fałszerstwa dokumentu (mianowicie sfałszowany podpis), co w żaden sposób nie wydaje się do pogodzenia ze swoistym dla Norwida imperatywem szczerości. W takim postępowaniu można by ujrzeć akt chrześcijańskiego miłosierdzia, jak to zreszta sugeruje cytat z Księgi Przysłów $(22,19)$. Sądzę, że należy rozumieć tekst możliwie dosłownie co do „wycinania” i „naklejenia”, a więc do kolażu błędów korespondenta. Norwid prosi redakcję o podpisanie errat jego imieniem, by móc cierpieć zamiast korespondenta. Chodzi jednak częściowo o jego - Norwida - udział, o ile kolaż jest dziełem. Zapytać musimy więc podobnie jak w przypadku Pót-listu: gdzie w tej operacji ma miejsce szukany „czyn ze słowa”? Czy „akt” czytania - ów kolaż errat - ma być uznany za ten czyn? Czy też ma nim być raczej gest ofiarnego podpisania? Operacja chyba składa się $\mathrm{z}$ obu wątków, gdyż Norwid chce pokazać modelowo, że ze słowa per se w żadnym razie nie wynika nowa rzeczywistość, tzn. że teksty nigdy nie maja automatycznych skutków. Poniekąd ta demonstracja nawiązuje do Mickiewiczowskiej polemiki przeciwko wydrukowanej literaturze z prelekcji paryskich. Jeśli zaś Mickiewicz pokładał nadzieje w charyzmatycznym pulsującym „Słowie”, Norwid pozostaje wyraźnym sceptykiem. Słowo - zdaje się mówić - nie jest o wiele żywsze niż „umierająca litera”. Musi więc przejmować umieranie, doświadczać go i w taki sposób poświęcać się sferze znajdującej się całkowicie poza nim. morskiej), Kalendarz życia i twórczości Cypriana Norwida. T. 1: 1821-1860. Poznań 2007. s. 426,445 . 
Radykalność czy surowa ironiczność rozważań Norwida wyobcowała go ze środowiska „Gońca Polskiego”. Ilustruje to kolejny felieton Dienheima-Chotomskiego z serii Błędny ognik z kwietnia 1851. Wciąż na nowo biorąc na muszkę Promethidiona, dziennikarz wyraża pogardę dla myśli i stylu Norwida. Co ciekawe, w polemice podejmuje problematyke „,wielkiego” i „małego”. Chyba nie zaskakuje to, że jako miara wielkości oraz wzniosłej egzaltacji służy mu Mickiewicz:

Kto wieszcz, niech odkrywa nowe kierunki duchowi czasu, a „przenikając okiem słońca ludzkości całe ogromy" [zmodyfikowany cytat z Ody do młodości - Ch. Z.], niech je do celów przez proroków przepowiedzianych wiedzie ${ }^{37}$.

Według Dienheima-Chotomskiego pewna gradacja prowadzi od „poety” przez „marzyciela” do „drobnostkowca”. Ten ostatni ma, rzecz jasna, charakteryzować Norwida. Felietonista kontynuuje:

Kto d r ob no s t kow i e c, niech z mikroskopem w ręku śledzi straszliwe dramata robaków w kropelce, a rzucając anathema na tych, co się z niego śmieją, niech się ubóstwia, że nowe odkrywa światy, i niech się stracha nad okropnościami infuzjonicznymi ${ }^{38}$.

Z autorem Promethidiona wiąże zatem głęboki upadek proroczych wyżyn romantyzmu w płaskość idiosynkratycznej mikrokosmiczności. Pewnie to nie przypadek, że Dienheim-Chotomski parodiuje również koncepcję słowa jako „testamentu”39. Z jego tekstu nie wynika jednak, czy autor zauważył kalambur z „testem”. Pisze konsekwentnie, choć absurdalnie: „dla nas testament czynu jest c zy n e m”40. To znaczy, że faza „testujacca” nie jest mu potrzebna. Intermedium pomniejszenia czynu okazuje się stratą czasu. Nietrudno określić, co ta krytyka przeocza. Nie zauważa - niedobrowolnie na to wskazując - iż motywem pomniejszenia jest dążenie do powszechności. Jak to pokazałem przez porównanie Norwida ze Stifterem, pomniejszenie ma za każdym razem ukazywać ważność wyższego rzędu. Odwrotnie, te „wielkie” zjawiska wydają się partykularnymi, z kolei wywyższenie patrzącego na przyrodę - jak Kant opisywał oddziaływanie wzniosłości - co najwyżej osiagnięciem subiektywnym.

Norwid stara się wprowadzić „największe” w „najmniejsze” według paradygmatu wcielenia Boga. Przejmując od systemu romantycznego „czyn” jako część składową, poeta rozumie go już nie erupcyjnie, lecz jako ciąłła pracę nad „zamykaniem” koła. $Z$ jednej strony, jako późny romantyk opiewa naród polski, z drugiej zaś - wyobraża Polskę pomniejszoną, by przydać jej status bardziej uniwersalny. Ostatnie zagadnienie, które omówiłem - myślenie „testamentalne” o literaturze - również wynika z zamiaru uniwersalistycznego, choć w mniej oczywisty sposób. Norwidowska persona poetycka jest zawsze pojedyncza. Pisanie jako sporządzenie testamentu to antycypacja takiego stanu, który radykalnie wymyka się piszącemu - antycypacja bez żadnego osobistego udziału w tym, co projektuje. Gotowość do takiej 
ofiary to obowiązek, który Norwid nakłada na swoją personę poetycką. Można wręcz mówić o maksymalizmie minimalizacji: w swoich mikrointerwencjach („Chcecie c zyn u ze słowa - oto macie!") wskazuje palcem na brak czynu, to znaczy na niezupełność literatury i dezyderat etyki w Polsce i na całym świecie.

\author{
Abstract \\ CHRISTIAN ZEHNDER University of Fribourg \\ ORCID: 0000-0003-4442-0093 \\ THE SMALLEST UNIVERSALITY NORWID'S SCALE OF ACTIVISM
}

This article attempts a reassessment of Cyprian Norwid's response to Romantic activism. The model promoted by Norwid himself-the replacement of action (czyn) by labor (praca) - has the disadvantage of presupposing a vague concept of labor that ultimately refers back to action. This article uses Harold Bloom's concept of an "internalization" of revolutionary prometheism in late Romanticism to show, by contrast, how Norwid formally downscales activism. The focus on the "small" allows for a new juxtaposition with the Biedermeier, a distinctive Central European current of the time, in general and Adalbert Stifter's "gentle law" (das sanfte Gesetz) in particular. This article then takes a closer look at three cases of downscaling in Norwid's writings: the modeling of action as circle and wheel (koło) in Promethidion (1851) and other writings, the paradoxical demonstration of why God's omnipotence reveals itself within the realm of the "small" in Biate kwiaty (White Flowers, 1856-1857) as well as a series of ironic micro-simulations of the "deed from the word" (czyn ze słowa), which are meant to expose conventional Romantic activism as magical thinking. 